\title{
BOILED CHICKEN EGGS AGAINST RATE OF PERINEUM TEARS ON POSTPARTUM MOTHERS IN KRAMAT HEALTH CENTER, TEGAL REGENCY
}

\author{
Nurhayati1), Iroma Maulida $^{2)}$, Adevia Maulidya Chikmah ${ }^{3)}$ \\ Email: iroma.maulida@yahoo.co.id \\ 1,2,3 Diploma III Kebidanan Politeknik Harapan Bersama Tegal
}

\section{Article Information}

Received:

October 30, 2019

Revised:

December 26, 2019

Accepted:

January 19, 2020

Available online:

January 23, 2020

\begin{abstract}
Injuries after childbirth are one of the causes of labour infections among other causes. Factors that can accelerate wound healing include nutrition. Nutrition plays a role in helping the process of metabolism, maintenance and formation of new tissue. Egg whites contain more nutrients than egg yolks which can heal perineal suture wounds in mothers after childbirth. The study population was postpartum mothers with perineal suture wounds at Kramat Public Health Center on January 7-February 2, 2019. This study used a quasi-experimental design with the Pretest and Posttest With Control Group Design approach, where respondents divided into intervention groups and control groups of 20 respondents. The wound degree observed at the beginning of the observation and the rate of wound healing at the end. In the intervention group, the respondent required to eat five egg whites for six days. Data analysis was performed with ANOVA test ( $\alpha$ : $5 \% ; 95 \%$ Confident Interval) to see the effect of consumption patterns of chicken egg white with the level of wound healing perineum. The results showed an influence of consumption patterns of boiled chicken egg white on the rate of perineal suture wounds healing as indicated by the higher number of respondents with a reasonable wound healing rate in the intervention group of $62.5 \%$ ( 5 people) compared to the control group, which was $42.9 \%$ (3 people) and from the Anova test results obtained a p-value of 0.015 . Thus it is recommended that postpartum mothers consume many egg whites in order to accelerate the healing of perineal wounds to prevent infections due to perineal wounds.
\end{abstract}

Keywords: Egg white, Perineal suture wounds Healing

\section{Introduction}

In 2010 - 2013, infection occupies the 3rd most significant cause of maternal death and has increased from 2012 by $5.6 \%$ compared to 2013 by $7.3 \% .^{[1]}$ Postpartum injuries such as labour wounds, mastitis, thrombophlebitis and pelvic inflammation are still cause of infection. Other factors causing puerperal infections include lack of endurance, puerperal care that was not good, as well as malnutrition, anemia, poor hygiene and fatigue. Efforts to monitor care for mothers and babies during childbirth are Chicken eggs were cheap and easy to get. The complex protein in egg white contains all the essential amino acids the body needs. Protein helps the body's metabolic processes, maintenance and formation of new tissues. In order to prevent infection by accelerating the healing of labour wounds, this study aimed to analyze the effect of consumption patterns of boiled 
chicken egg white on the rate of wound healing of perineal suture wounds in postpartum mothers at the Kramat Public Health Center in Tegal Regency. Many similar studies had been done but were more focused on the rate of healing of perineal suture wounds in terms of healing time, which was said to be fast if wound healing was less than six days. The study conducted by Aisya et al. in the Pulubala Public Health Center area of Gorontalo Regency in 2017 to analyze the effectiveness of consumption of boiled egg white for the healing process of perineal wounds. Whereas in this study, the rate of perineal suture wound healing factor in the study respondents was observed at the same time, i.e. the $7^{\text {th }}$ day since childbirth. Determined observations carried out on the $7^{\text {th }}$ day since childbirth because the healing of wounds perineum generally will heal within 6-7 days postpartum. ${ }^{[3]}$ In this study also seen the degree of labour wounds / perineal wounds and behaviour of perineal wound care because both variables affect the rate of healing of perineal wounds.

\section{Method}

The population in this study was postpartum mothers with first degree and second degree of perineal sutures wound at the Kramat Public Health Center on January 7-February 2, 2019. Twenty people took as the sample. The study used a quasi-experimental approach to the Pretest and Posttest with Control Group Design, where respondents divided into an intervention group and control group. Systematic random sampling used to determine the respondents into the intervention group or the control group by determining the respondents alternately into the intervention group and the next respondent entering the control group. In the beginning, the degree of respondents perineal wound observed. And the end of observation. Furthermore, the rate of healing observed in the end. In theory, it stated that wound healing was the process of replacing and repairing damaged tissue in 6-7 days postpartum. ${ }^{[4]}$ Therefore, the rate of healing of perineal wounds in respondents observed on the 7th day after childbirth. If the respondent was unable to attend postpartum checkup in Public Health Center during the seven days after childbirth, we visited respondents house with the village midwife to observe or measure the level of perineal wound healing. The criteria for wound healing grouped into excellent, moderate and poor.

In the intervention group, respondents required to eat five egg whites for six days. To ensure respondents consumed the egg whites, respondents encouraged to send photos via smartphone via WhatsApp. Data analysis performed with ANOVA test ( $\alpha$ $=5 \% ; 95 \%$ Confident Interval) to analyzed the effect of consumption patterns of chicken egg white on the rate of healing of perineal wounds.

\section{Results and Discussion}

The results of this study shown in Table 1 below.

Table 1 Frequency Distribution of Perineal Suture Wound Degrees, Wound Care and the Rate of Wounds Healing in the Intervention and Control Groups.

\begin{tabular}{|c|c|c|c|}
\hline Characteristic & $\begin{array}{c}\text { Interven } \\
\text { tion } \\
\text { Group }\end{array}$ & $\begin{array}{c}\text { Control } \\
\text { Group }\end{array}$ & Total \\
\hline & $\begin{array}{l}\text { f } \% \\
\mathrm{~N}=\mathbf{1 0}\end{array}$ & $\begin{array}{l}\text { f } \% \\
\mathrm{~N}=\mathbf{1 0}\end{array}$ & 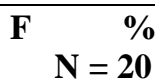 \\
\hline
\end{tabular}

Perineal Suture Wound Degrees

$\begin{array}{lllllll}\text { First Degree } & 3 & 42.9 & 4 & 57.1 & 7 & 100\end{array}$

$\begin{array}{lllllll}\text { Second } & 7 & 53.9 & 6 & 46.1 & 13 & 100\end{array}$

Degree

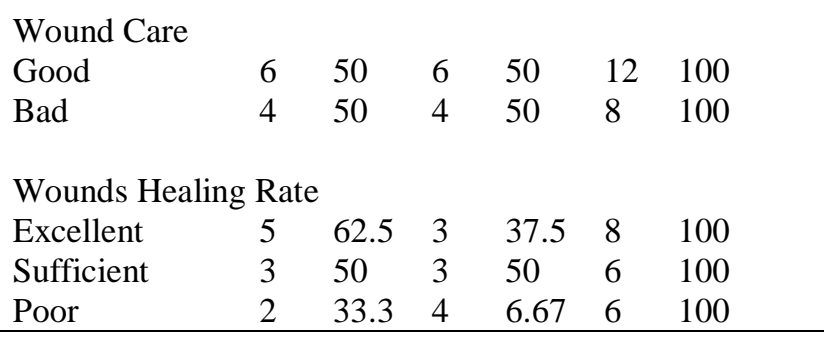

Characteristics of the degree of the wound in the intervention group and control group respondents were the most 
common in the second degree and almost the same number; this showed from the percentage of respondents who suffered second-degree injuries in the intervention group, which was $53.9 \%$ (7 respondents) and in the control group, the most also suffered second-degree injuries of $46.1 \%$ (6 respondents). In this study showed that there is little possibility the degree of wound influence the level of wound healing as shown by the number of respondents who experienced almost the same degree of wound. Though in theory stated that the degree of wound would affect the length of time of healing. The higher degree of the perineal wound will affect the healing rate. ${ }^{[5]}$

As well as wound care factors; in this study, the number of respondents with excellent wound care characteristics had the same number between the intervention and control group, i.e. 50\% (6 respondents). This result shows that there is no effect on the rate of perineal wound healing. Although in theory stated that wound care is one of the internal factors that could influence the rate of perineal wounds healing, in addition to age, degree of tear, parity and genetic factors.

In the intervention group from table 1, the majority of respondents experienced good wound healing by $62.5 \%$ (5 respondents). Whereas in the control group, most of the respondents experienced poor wound healing, which was $60.67 \%$ (4 respondents). The criteria for evaluating perineal wound healing in this study were excellent if the wound was dry, the perineum wound closes, and there were no signs of infection such as red, swollen, festering and fever. While the moderate healing, if the wound was dry or wet, the perineum wound closes and there are no signs of infection such as red, swollen, festering and fever. Furthermore, poor healing, if the wound was wet, the perineum wound opens, and there were signs of infection such as redness, swelling, suppuration and fever. ${ }^{[6]}$

The results of this study are in line with other references that mentioned the benefits of egg whites where the majority of respondents usually heal within 6-7 days while respondents who did not consume boiled eggs on average need 714 days to recover. Recovery time for postpartum mothers who consumed boiled eggs was faster 1-7 days. ${ }^{[5]}$

After being analysed with
ANOVA, it is known the significance/existence of a relationship between the consumption pattern of boiled chicken egg white with the cure rate obtained a p-value $=0.015$ (less than $0.05)$. This result is in line with the theory which explains that egg whites could heal perineal suture wounds in postpartum mothers because they contain a lot of complex proteins that contain essential amino acids thereby accelerating the healing of perineal wounds in the puerperium. ${ }^{[7]}$

In other words, wound healing requires amino acids to repair and form new tissues ${ }^{[3]}$. Amino acids are abundant in proteins, and proteins in egg whites contain complete amino acids compared to other animal proteins.

Protein on one portion of egg white (3.6 grams) is higher than protein in one portion of egg yolk (2.7 grams). Also, the protein found in egg white contains all the essential amino acids needed by the body. ${ }^{[8]}$

Egg white protein is rich in nutrients such as niacin protein, riboflavin, chlorine, magnesium, potassium, sodium, ovalbumin..$^{[7]}$ Also, protein can increase the body's ability to fight infections and diseases that can accelerate healing. ${ }^{[9]}$

\section{Conclusion}

From the results of the study, it is known that there is a correlation between the consumption pattern of boiled chicken egg white with the healing rate of perineal suture wound in puerperal mothers at the Kramat Public Health Center in Tegal Regency. The result from observation of perineal wounds carried out on the $7^{\text {th }}$ day postpartum. (pvalue $=0.015 ; 95 \% \mathrm{CI})$. The health workers should advise mothers who have 
perineal wounds to eat egg whites during the wound healing period. Similar research also needs to be done with multivariate analysis of several factors that affect the healing of perineal wounds given that this study is still limited, only a bivariate analysis between consumption of egg whites and healing of perineal wounds.

\section{References}

[1] Kementerian Kesehatan (Kemenkes) RI. Profil Kesehatan Indonesia tahun 2013. Jakarta: Kementerian Kesehatan RI; 2014.

[2] Tulas D, Verby, Kundre R dan Bataha Y. Hubungan Perawatan Luka Perineum Dengan Perilaku Personal Hygiene Ibu Post Partum Di Rumah Sakit Pancaran Kasih Gmim Manado. Jurnal Keperawatan. 2017. 5(1)

[3] Aisya M, Usman S, Dali R. Efektifitas Konsumsi Putih Telur Rebus Terhadap Proses Penyembuhan Luka Perineum di Wilayah Puskesmas Pulubala Kabupaten Gorontalo. Jurnal Ilmiah Umum dan kesehatan 'Aisyiah, 2018. 3(1)

[4] Boyle M. Pemulihan LukaSeri Praktik Kebidanan. Jakarta:EGC; 2009.

[5] Rukiyah. Asuhan Kebidanan III (Nifas). Jakarta: Trans Info Media; 2010.

[6] Masadah. Perawatan Luka. Jakarta: EGC; 2010.

[7] Setyowati E. Perbedaan Efektifitas Pemberian Putih Telur Dan Ikan Gabus Terhadap Penyembuhan Luka Perineum Ibu Nifas. Jurnal ) Akademi Kebidanan Griya Husada Surabaya. 2014. 2(1)

[8] U.S Departement Of Agriculture Nutrient Data Laboratory. Nutrional value of eggwhites versus egg. Internet. Diakses di https://ahealthiemichigan.org/2011/ 10/11diakses tanggal 18 Desember 2018
[9] Rifani U. Penerapan Konsumsi Telur Ayam Rebus Untuk Percepatan Penyembuhan Luka Perineum Pada Ibu ifas Di BPM Heni Winarti Desa Jatijajar, Ayah, Kebumen. Skripsi. Gombong: STIKES Muhammadiyah Gombong; 2017. 